\title{
Botanical origin and antioxidant activities of propolis from the Irano-Turanian region
}

\author{
İlginç Kızılpınar Temizer ${ }^{1, *}$, Aytaç Güder ${ }^{1}$, Ömür Gençay Çelemli² \\ 'Vocatinal High School of Health Services, Giresun University, 28200, Giresun, Turkey \\ 2Department of Biology, Science Faculty, Hacettepe University, 06800, Ankara, Turkey
}

Cite this article as: Kızılpınar Temizer I, Güder A, Gençay Çelemli Ö (2017). Botanical origin and antioxidant activities of propolis from the Irano-Turanian region. Istanbul J Pharm 47 (3): 107-111.

\begin{abstract}
Propolis is a natural bioactive mix and a traditional medicine that has been used for treating several complications. The bioactive properties of propolis are dependent on its botanical origin. This study investigated the pollen composition, antioxidant activities, and the total phenol and total flavonoid content of a propolis sample from the Refahiye (Erzincan, Turkey) region. Melissopalynological analysis conducted according to the relevant literature revealed that the pollen profile of the sample primarily indicated the presence of the Fabaceae (38.4\%), Asteraceae $(20.2 \%)$, and Fagaceae (11.2\%) families. The antioxidant ability of propolis extract was analyzed by the hydrogen peroxide scavenging activity (HPSA) (in terms of SC50), ferric reducing antioxidant power capacity (FRAP) (\%), DPPH radical scavenging activity (in terms of SC50), metal-chelating activity (\%), total phenol content (TPC), and total flavonoid content (TFC), which showed the following values: $11.72 \pm 0.04 \mu \mathrm{g} / \mathrm{mL}, 90.73 \% \pm$ $0.24 \%, 18.34 \pm 0.08 \mu \mathrm{g} / \mathrm{mL}, 89.69 \% \pm 0.12 \%, 10673.4 \pm 3.30 \mathrm{mg} \mathrm{GAE} / 100 \mathrm{~g}$ of propolis sample (PS), and $170.65 \pm 1.12 \mathrm{mg}$ QE/100 $\mathrm{g}$ of PS, respectively. These results were compared using butylated hydroxyanisole (BHA), butylated hydroxytoluene (BHT), and $\alpha$-tocopherol (TOC) as standard antioxidant compounds. The high biological activity of propolis from the Refahiye region could be attributed to its rich pollen composition. These results indicate that propolis is an important source in terms of its antioxidant activities.
\end{abstract}

Keywords: Bioactive properties, melissopalynological analysis, propolis, Refahiye (Erzincan)

\section{INTRODUCTION}

Propolis (bee glue) is a sticky dark-colored material that is collected from honeybee plants (buds and leaves), which is mixed with pollen as well as enzymes secreted by bees (Marcucci 1995). The term "propolis" has been derived from two Greek words, i.e., "pro" stands for "at the entrance to" and polis for "community" or "city" (Wagh 2013). Bees use propolis in their hives as a protection against predators and microorganisms, to repair damage, as a thermal isolator, and to build aseptic locals to prevent microbial infection of larvae (Bankova et al. 2000; Huang et al. 2014). Propolis has a wide spectrum of biological activities and has been used for various purposes by the people. Several studies have investigated the antibacterial (Sforcin et al. 2000; Hegazi and Abd El Hady 2001), antifungal (Ota et al. 2001; Herrera et al. 2010), anti-inflammatory (Borrelli et al. 2002), anticancer (Sawicka et al. 2012), antioxidant (Perveen and Qaiser 2007; Kalogeropoulos et al. 2009; Silva et al. 2013), and antitumor (Oršolić \& Bašić 2003; Sobočanec et al. 2011) properties of propolis. The chemical ingredients of propolis have been reported to be highly variable and dependent on the native flora (Bankova et al. 2000; Kumazawa et al. 2004; Silva et al. 2008). Turkey has a great diversity of plants comprising more than 10,000 taxa with 173 families and about 2,650 endemic species (Davis 1965-1985; Özhatay 2013). However, propolis production has been generally ignored in Turkey, where several beekeepers focus on only the production of honey. The aim of the present study was to determine the quality of a propolis sample from the Irano-Turanian phytogeographic region of Turkey in terms of its antioxidant activity and botanical origin. 


\section{MATERIALS AND METHODS}

\section{Reagents and standards}

All the following reagents used were of proanalysis grade: 2,2-diphenyl-1-picrylhydrazyl, butylated hydroxyanisole, butylated hydroxytoluene, gallic acid, quercetin, a-tocopherol (Sigma), Folin-Ciocalteu reagent, and absolute ethyl alcohol (Merck). All other chemicals were of analytical grade.

\section{Sample collection}

Propolis sample was collected from the East Anatolia Region of Turkey, which covers the Irano-Turanian floral region (Davis 1965-1985).

\section{Sample solution}

The sample solution was prepared by mixing $1.33 \mathrm{~g}$ propolis with $100 \mathrm{~mL}$ absolute ethanol. This suspension was shaken at room temperature on a magnetic stirrer for $24 \mathrm{~h}$. Then, the extract solution was filtered through a Whatman no. 4 filter paper and stored at $-4^{\circ} \mathrm{C}$

\section{Palynological identification}

The study material was prepared for examination under the microscope according to the method of Warakomska and Maciejewic (1992). The sample was ground into powder, mixed with ethanol-ether-acetone (1:1:1), and then shaken. This mixture was filtered through a strainer with $0.3-\mathrm{mm}$ holes. The suspension was then centrifuged at 3500-4000 rpm for 20 min, after which the supernatant was discarded. Then, using the residual sediment, two slides were prepared for each sample using basic fuchsin glycerin gelatin and were examined simultaneously for determining the pollen count.

The identification of the stages of pollen grains was performed using an optical microscope (Nikon Eclipse Ci, Japan) at 400x and 1000x magnifications.

\section{Antioxidant analyses}

\section{Determination of 2,2-diphenyl-1-picrylhydrazyl (DPPH) free radical scavenging activity}

The DPPH radical scavenging activity was determined according to a previously reported method of Blois (1958) with few modifications. Serially diluted samples $(3.0 \mathrm{~mL})$ at different concentrations (10-100 $\mathrm{gg} / \mathrm{mL}$ ) were added to DPPH solutions $(1.0 \mathrm{~mL}, 0.2 \mathrm{mM}$ ) with ethanol. The mixtures were vigorously shaken and allowed to stand at room temperature for $30 \mathrm{~min}$. Then, the absorbance was recorded at $517 \mathrm{~nm}$ using a spectrophotometer, and the results were expressed as $\mathrm{SC}_{50}$ (the concentration required for scavenging $50 \%$ of DPPH) $(\mu \mathrm{g} / \mathrm{mL})$ by a linear regression analysis and represented as mean of the data.

\section{Determination of hydrogen peroxide scavenging activ- ity (HPSA)}

The HPSA was determined according to the method described by Ruch et al. (1989). Briefly, the samples were dissolved in 0.04 M phosphate buffer ( $\mathrm{pH}=7.4)$ and $3.4 \mathrm{~mL}$ of the sample was mixed with $0.6 \mathrm{~mL}$ of $40 \mathrm{mM} \mathrm{H}_{2} \mathrm{O}_{2}$ solution (prepared using the same buffer). The absorbance of the mixture was measured at $230 \mathrm{~nm}$ versus the blind sample after 10 min using a UVNIS spectrophotometer. Phosphate buffer without hydrogen per- oxide was used as blank. A decrease in the absorbance value indicated a high level of hydrogen peroxide scavenging activity. The results were expressed as $\mathrm{SC}_{50}$ values $(\mu \mathrm{g} / \mathrm{mL})$.

\section{Ferric reducing antioxidant power (FRAP) assay}

The reducing ability of the sample was investigated following a method using a ferric ion, with minor modifications (Güder et al. 2014). About $2.0 \mathrm{~mL}$ of the sample or standards was mixed with PBS (phosphate-buffered saline) $\left(2.0 \mathrm{~mL}, 0.2 \mathrm{~mol} \mathrm{~L}^{-1}, \mathrm{pH}\right.$ 6.6) and potassium ferricyanide $(2.0 \mathrm{~mL}, 1.0 \%)$. This mixture was incubated at $50^{\circ} \mathrm{C}$ for $20 \mathrm{~min}$, followed by the addition of trichloroacetic acid (2.0 mL, 10\%). Then, $2.0 \mathrm{~mL}$ of this solution was mixed with distilled water $(2.0 \mathrm{~mL})$ and $\mathrm{FeCl}_{3}(0.5 \mathrm{~mL}$, 0.1\%). The $\mathrm{Fe}^{3+} / \mathrm{Fe}^{2+}$ transformation was determined due to the presence of samples at $700 \mathrm{~nm}$.

$\operatorname{FRAP}(\%)=\left(A_{s} / A_{c}\right) \times 100$

Where, $A_{c}$ is the absorbance of the control, and $A_{s}$ is the absorbance of the sample or standards.

\section{Determination of metal-chelating activity}

The metal-chelating activities of the propolis extract and the standard antioxidant materials were estimated according to the method described by Dinis et al. (1994). Briefly, $0.05 \mathrm{~mL}$ of $2 \mathrm{mM} \mathrm{FeCl}_{2}$ and $0.4 \mathrm{~mL}$ of the extract solution were mixed. The reaction was initiated by the addition of $0.2 \mathrm{~mL}$ of $5 \mathrm{mM}$ ferrozine solution. This mixture was vigorously shaken and kept at room temperature for 10 min, after which the absorbance of the mixture was measured at $562 \mathrm{~nm}$ using a UV/ VIS spectrophotometer. A decrease in the absorbance value demonstrated a high level of metal-chelating activities of the extract solution and the standard antioxidant materials. The metal-chelating activities of the extract solution and the standard antioxidant material were calculated according to the following formula:

Ferrous ion chelating activity $(\%)=\left[1-\left(A_{s} / A_{c}\right)\right] \times 100$

Where, $A_{c}$ is the absorbance value of the control, and $A_{s}$ is the absorbance value of the extract solution or the standard antioxidant material

\section{Determination of total flavonoid content (TFC)}

The TFC of the extracts was determined according to the colorimetric method described by Chung (2002) with minor modifications. Sample solutions $(0.5 \mathrm{~mL})$ were added to a tube containing $1.5 \mathrm{~mL}$ of absolute ethanol. $\mathrm{AlCl}_{3} \cdot 6 \mathrm{H}_{2} \mathrm{O}$ solution $(0.1$ $\mathrm{mL}, 10.0 \%)$ and potassium acetate $\left(0.1 \mathrm{~mL}, 1.0 \mathrm{~mol} \mathrm{~L}^{-1}\right)$ were subsequently added to prepare the mixture. Distilled water was added to make up the total volume to $5.0 \mathrm{~mL}$, and then the absorbance was read after $30 \mathrm{~min}$ at $415 \mathrm{~nm}$. The TFC values were expressed as microgram of quercetin equivalent that was obtained from the standard graph $\left(R^{2}=0.9979\right)$.

\section{Determination of total phenolic content (TPC)}

The TPC of the samples was determined by the Folin-Ciocalteu phenol reagent (Folin C) colorimetric method described by Slinkard and Singleton (1977). The sample solutions $(0.5 \mathrm{~mL})$ were mixed with $7.0 \mathrm{~mL}$ of distilled water and subsequently with Folin C reagent $\left(0.5 \mathrm{~mL}\right.$ ). After $3 \mathrm{~min}, \mathrm{Na}_{2} \mathrm{CO}_{3}$ solution (3.0 
$\mathrm{mL}, 2.0 \%)$ was added to the mixture. The color developed after $1 \mathrm{~h}$, and then the absorbance was measured at $760 \mathrm{~nm}$ using a spectrophotometer. Gallic acid was used as the standard, and TPC was expressed as microgram of gallic acid equivalent using an equation that was obtained from the standard gallic acid graph $\left(R^{2}=0.9995\right)$.

\section{RESULTS AND DISCUSSION}

All the 18 pollen types (Table 1) belonging to 13 families were identified in the propolis sample. The identified pollen samples generally belonged to the Fabaceae (38.4\%), Asteraceae (20.2\%), and Fagaceae (11.2\%) families (Figure 1). The pollen spectra of the sample were found to overlap with those of the Refahiye vegetation. Gençay and Sorkun (2006) stated that 32 different plant families have been identified by the pollen analysis of 30 propolis samples from Kemaliye (Erzincan), and Apiaceae, Asteraceae, Campanulaceae, Fabaceae, Fagaceae, Lamiaceae, Liliaceae, Pinaceae, Rosaceae, Salicaceae, Rhamnaceae, and Scrophulariaceae families were primarily determined as the botanical origins of propolis. Çelemli and Sorkun (2012) analyzed the pollen spectra of 92 propolis samples collected from Tekirdağ and reported that the frequently observed pollen grains belonged to the Asteraceae, Boraginaceae, Brassicaceae, Fabaceae, and Salicaceae families. These results are consistent with those of our study.

The HPSA, FRAP, DPPH radical scavenging activity, metal-chelating activity, TPC and TFC values are as follows: 11.72 \pm 0.04 $\mu \mathrm{g} / \mathrm{mL}, 90.73 \% \pm 0.24 \%, 18.34 \pm 0.08 \mu \mathrm{g} / \mathrm{mL}, 89.69 \% \pm 0.12 \%$, $10673.4 \pm 3.30 \mathrm{mg} \mathrm{GAE} / 100 \mathrm{~g}$ of PS, and $170.65 \pm 1.12 \mathrm{mg}$ QE/100 $\mathrm{g}$ of PS, respectively. These results were compared using butylated hydroxyanisole (BHA), butylated hydroxytoluene (BHT), and a-tocopherol (TOC) as standard antioxidant compounds. The obtained results of the standards are presented in Table 2. Moreira et al. (2008) reported the DPPH radical scavenging activities of two propolis samples (Bornes and Fundão) as $6 \pm 3$ and $52 \pm 3 \mu \mathrm{g} / \mathrm{mL}$, respectively. In addition, they reported the TPC of the same samples as 32900 and 15100 mg GAE/100 g, respectively. Based on these literature data, our results showed an average DPPH radical scavenging activity but a lower TPC.

Popova et al. (2005) investigated the TPC of Turkish propolis samples (from Adana, Artvin, Erzurum, Izmir, Kayseri, and Yozgat) and reported TPC values of 8.2\%-30.4\%. In the Irano-Turanian samples (Erzurum, Kayseri, and Yozgat), the TPC values were $10.5 \%, 27.5 \%$, and $26.4 \%$ respectively. Our results were found to be consistent with these literature data.

Lima et al. (2009) reported the TPC values of the methanolic propolis extract as 25700-39300 mg GAE/100 g. In addition, the TFC was found to be between 6600 and $13300 \mathrm{mg}$ QE/100 g. Wali et al. (2015) analyzed the propolis samples collected from the Kashmir-Himalayan region using different extraction solvents (ethanol, water-ethanol, and water) and reported TPC and TFC values of 18000-26000 mg GAE/100 g and 4500$10500 \mathrm{mg}$ QE/100 g, respectively. Ahn et al. (2007) studied the propolis samples collected from different parts of China and reported that the TPC values ranged from $42.9 \pm 0.8$ to $302 \pm 4.3$ $\mathrm{mg} \mathrm{GAE} / \mathrm{g}$ of samples and the TFC values ranged from $8.3 \pm 3.7$

\section{Table 1. Pollen types identified from Refahiye propolis}

\begin{tabular}{|lccc|}
\hline Taxa/Family & $\%$ & Taxa/Family & $\%$ \\
\hline Apiaceae & 1.2 & Fagaceae & \\
Asteraceae & & Quercus & 11.2 \\
Echinate type & 9.2 & Lamiaceae & 2.6 \\
Scabrate type & 1.2 & Thymus & 1 \\
Xanthium & 2 & Phlomis & 0.6 \\
Taraxacum & 1.8 & Rosaceae & 1.8 \\
Carthamus & 4.2 & Sanguisorba & 0.6 \\
Centaurea & 1.8 & Salicaceae & \\
Betulaceae & & Salix & 5 \\
Betula & 0.4 & Populus & 4 \\
Boraginaceae & 8.8 & Pinaceae & \\
Onosma & 0.6 & Pinus & 0.2 \\
Brassicaceae & 0.6 & Poaceae & 0.6 \\
Campanulaceae & 1 & Unidentified & 1.2 \\
Fabaceae & 20.2 & & \\
Astragalus & 10.2 & & \\
Onobrychis & 8 & & \\
\hline
\end{tabular}

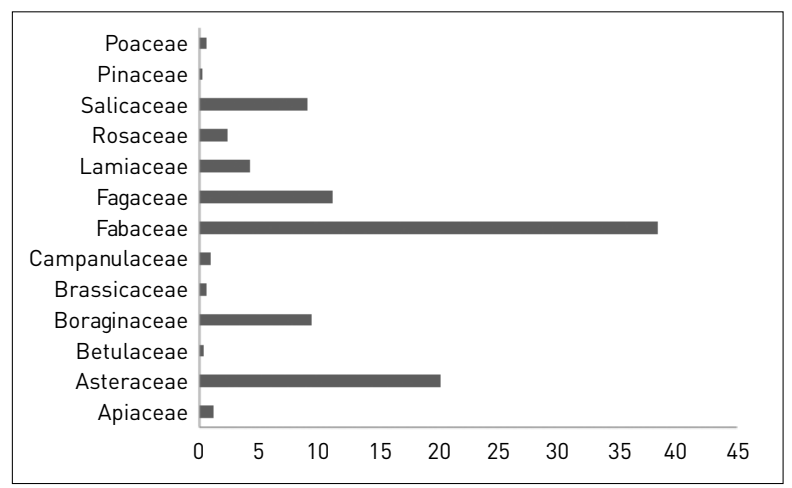

Figure 1. Distribution of families of which the pollens were identified from Refahiye propolis

to $188 \pm 6.6 \mathrm{mg} \mathrm{QE} / \mathrm{g}$ of samples. Choi et al. (2006) found the TPC value of Korean propolis samples collected from Yeosu to be 212.7 $\pm 7.4 \mathrm{mg} \mathrm{GAE} / \mathrm{g}$, and Kumazawa et al. (2004) reported that the TPC and TFC values of propolis ranged from 31.2 \pm 0.7 to $299 \pm 0.5 \mathrm{mg} \mathrm{GAE} / \mathrm{g}$ and from $2.5 \pm 0.8$ to $176 \pm 1.7 \mathrm{mg} \mathrm{QE} / \mathrm{g}$, respectively, collected from different geographic regions. Laskar et al. (2010) showed that the TPC and TFC values ranged from $159.10 \pm 0.26$ to $269.10 \pm 0.17 \mathrm{mg} \mathrm{GAE} / \mathrm{g}$ and from $57.25 \pm 0.24$ to $25.50 \pm 0.36 \mathrm{mg} Q \mathrm{Q} / \mathrm{g}$, respectively, in Indian propolis samples. The TPC and TFC values are comparable with the literature data because of the average contents. Furthermore, the DPPH radical scavenging activity and the HPSA were found to be 18.34 and $11.72 \mu \mathrm{g} / \mathrm{mL}$, respectively. Gülçin et al. (2010) have also reported the DPPH radical scavenging activity and the HPSA of the lyophilized aqueous extract of propolis collected from 
Table 2. Antioxidant test results of the sample and standards

\begin{tabular}{|c|c|c|c|c|c|c|}
\hline & HPSA $^{1}$ & FRAP $^{2}$ & $\mathrm{DPPH}^{1}$ & $\mathrm{TPC}^{3}$ & $\mathrm{TFC}^{4}$ & $\mathrm{MCA}^{2}$ \\
\hline Propolis & $11.72 \pm 0.04$ & $90.73 \pm 0.24$ & $18.34 \pm 0.08$ & $10673.4 \pm 3.30$ & $170.65 \pm 1.12$ & $89.69 \pm 0.12$ \\
\hline $\mathrm{BHA}$ & $184.13 \pm 1.19$ & $92.02 \pm 0.80$ & $8.53 \pm 0.39$ & - & - & $89.95 \pm 0.05$ \\
\hline BHT & $147.49 \pm 0.09$ & $54.16 \pm 0.10$ & $9.01 \pm 0.02$ & - & - & $86.26 \pm 0.15$ \\
\hline TOC & $216.26 \pm 0.47$ & $32.98 \pm 0.21$ & $11.97 \pm 0.07$ & - & - & $93.41 \pm 0.06$ \\
\hline \multicolumn{7}{|c|}{$\begin{array}{l}{ }^{1} \mathrm{SC}_{50}(\mu \mathrm{g} / \mathrm{mL}) \\
2 \% \text { activity } \\
{ }^{3} \mathrm{mg} \mathrm{GAE} / 100 \mathrm{~g} \text { of PS } \\
{ }^{4} \mathrm{mg} \text { QE/ } 100 \mathrm{~g} \text { of PS } \\
\text { BHA: butylated hydrox }\end{array}$} \\
\hline
\end{tabular}

Erzurum as 31.81 and $6.54 \mu \mathrm{g} / \mathrm{mL}$ in terms of $I C_{50}$ after analyzing the polyphenol contents and the antioxidant activity. Our sample showed a higher DPPH radical scavenging activity than that of the Erzurum sample, but lower HPSA. Moreira et al. (2008) studied two Portugal propolis samples collected from different regions and determined the DPPH radical scavenging activities to be 0.006 and $0.052 \mathrm{mg} / \mathrm{mL}$, respectively (in terms of $\mathrm{EC}_{50}$ ). Laskar et al. (2010) determined the DPPH radical scavenging activities of propolis in terms of $\mathrm{IC}_{50}$ values to be $0.05-0.07 \mathrm{mg} / \mathrm{mL}$. The DPPH radical scavenging activities of Brazil propolis was found to be $3.17-8.79 \mathrm{mg} / \mathrm{mL}$ (Pontis et al. 2014). The DPPH radical scavenging activity of our sample was the highest among all the literature samples, except the Portugal propolis sample. Gülçin et al. (2010) found the FRAP activity to be 0.568 (absorbance value at $700 \mathrm{~nm}$ ). Compare this value with our result, it was very lower than that of our sample. The metal-chelating activity of propolis was determined as $89.69 \%$, and those of the standard compounds (BHA, BHT, and TOC) were found to be $89.95 \%, 86.26 \%$, and $93.41 \%$, respectively. Gülçin et al. (2010) calculated the metal-chelating activity using EDTA as a reference standard and reported a value of 12.04 $\mu \mathrm{g} / \mathrm{mL}$ of Fe $\mathrm{F}^{+2-}$ chelating activity for the Erzurum propolis sample, which was lower than those of the standard compounds (BHA, BHT, and TOC). However, our sample showed a similar activity as those of the standard compounds, especially BHA. Geckil et al. (2005) determined the metal-chelating activities of different extracts of Malatya propolis and reported values of 56\%-70\%. Geckil et al. (2005) also reported lower metal-chelating activities of propolis samples than those of the standard compounds (BHA and BHT). Subsequently, the Erzincan propolis sample demonstrated effective chelating activity than that by the Erzurum propolis sample. Therefore, the results of this study show that our propolis samples exhibited highly effective antioxidant activities.

\section{CONCLUSION}

This study showed that the propolis sample collected from the Refahiye (Erzincan, Turkey) region has an average antioxidant activity in comparison with the literature data. Therefore, it can be used as a natural source in the medicine and food industry. Especially, the active components in the propolis sample can be isolated and characterized. In this context, these active components can be used as potential treatment agents for certain diseases.

\section{REFERENCES}

- $\quad$ Ahn M, Kumazawa S, Usui Y, Nakamura J, Matsuka M, Zhu F, Nakayama T (2007). Antioxidant activity and constituents of propolis collected in various areas of China. Food Chem 101: 1383-1392. [CrossRef]

- $\quad$ Bankova VS, De Castro SL, Marcucci MC (2000). Propolis: Recent advances in chemistry and plant origin. Apidologie 31: 3-15. [CrossRef]

- Blois MS (1958). Antioxidant determinations by the use of a stable free radical. Nature 181: 1199-1200. [CrossRef]

- $\quad$ Borrelli F, Maffia P, Pinto L, lanaro A, Russo A, Capasso F, lalenti A (2002). Phytochemical compounds involved in the antiinflammatory effect of propolis extract. Fitoterapia 73: 53-63. [CrossRef]

- Choi YM, Noh DO, Cho SY, Suh HJ, Kim KM, Kim JM (2006). Antioxidant and antimicrobial activities of propolis from several regions of Korea. Lwt 39: 756-761. [CrossRef]

- $\quad$ Chung YC, Chang CT, Chao WW, Lin CF, Chou ST (2002). Antioxidative activity and safety of the 50 ethanolic extract from red bean fermented by Bacillus subtilis Imr-Nk1. J Agr Food Chem $\mathbf{5 0}$ 2454-2458. [CrossRef]

- $\quad$ Çelemli ÖG, Sorkun K (2012). The plant choices of honey bees to collect to propolis in Tekirdag-Turkey. Hacettepe J Biol \& Chem 40: 45-51.

- Davis PH (ND). Flora of Turkey and the East Aegean islands. Edinburgh University Press, Edinburgh.

- $\quad$ Dinis TCP, Madeira VMC, Almeida LM (1994). Action of phenolic derivatives (Acetaminophen, Salicylate, And 5-Aminosalicylate) as inhibitors of membrane lipid peroxidation and as peroxyl radical scavengers. Arch Biochem Biophys 315: 161-169. [CrossRef]

- Geckil H, Ates B, Durmaz G, Erdogan S, Yilmaz I (2005). Antioxidant, free radical scavenging and metal chelating characteristics of propolis. AM J Biochem and Biotech 1: 27-31. [CrossRef]

- Gençay Ö, Sorkun K (2006). Microscopic analysis of propolis samples collected from East Anatolia (Kemaliye-Erzincan). FABAD J Pharm Sci 31: 192-197.

- Güder A, Korkmaz H, Gökce H, Alpaslan YB, Alpaslan G (2014). Isolation, characterization, spectroscopic properties and quantum chemical computations of an important phytoalexin resveratrol as antioxidant component from Vitis labrusca L. and their chemical compositions. doi: 10.1016/j.saa.2014.05.056. [CrossRef]

- Gülçin I, Bursal E, Şehitoğlu MH, Bilsel M, Gören AC (2010). Polyphenol contents and antioxidant activity of lyophilized aqueous extract of propolis from Erzurum, Turkey. Food Chem Toxicol 48 2227-2238. [CrossRef]

- Hegazi AG, Abd El Hady FK (2001). Egyptian propolis: 1-Antimicrobial Activity And chemical composition of upper Egypt propolis. Z Naturforsch C 56: 82-88. [CrossRef] 
- Herrera CL, Alvear M, Barrientos L, Montenegro G, Salazar LA (2010). The antifungal effect of six commercial extracts of Chilean propolis on Candida spp.. Cien Inv Agr 37: 75-84. [CrossRef]

- Huang S, Zhang CP, Wang K, Li G, Hu FL (2014). Recent advances in the chemical composition of propolis. Molecules 19: 1961019632. [CrossRef]

- Kalogeropoulos N, Konteles SJ, Troullidou, E, Mourtzinos I, Karathanos VT (2009). Chemical composition, antioxidant activity and antimicrobial properties of propolis extracts from Greece and Cyprus. Food Chem 116: 452-461. [CrossRef]

- Kumazawa S, Hamasaka T, Nakayama T (2004). Antioxidant activity of propolis of various geographic origins. Food Chem $\mathbf{8 4}$ 329-339. [CrossRef]

- Laskar RASI, Roy N, Begum NA (2010). Antioxidant activity of Indian propolis and its chemical constituents. Food Chem 122 233-237. [CrossRef]

- Lima B, Tapia A, Luna L, Fabani MP, Schmeda-Hlrschmann G, Podio NS, Feresin GE (2009). Main flavonoids, dpph activity, and metal content allow determination of the geographical origin of propolis from the province of San Juan (Argentina). J Agr Food Chem 57: 2691-2698. [CrossRef]

- Marcucci MC (1995). Propolis: Chemical composition, biological properties and therapeutic activity. Apidologie 26: 83-99. [CrossRef]

- Moreira L, Dias LG, Pereira JA, Estevinho L (2008). Antioxidant properties, total phenols and pollen analysis of propolis samples from Portugal. Food Chem Toxicol 46: 3482-3485. [CrossRef]

- Oršolić N, Bašić I (2003). Immunomodulation by water-soluble derivative of propolis: A factor of antitumor reactivity. J Ethnopharmaco/ 84: 265-273. [CrossRef]

- Ota C, Unterkircher C, Fantinato V, Shimizu MT (2001). Antifungal activity of propolis on different species of Candida. Mycoses 44 375-8. [CrossRef]

- Özhatay N, Kültür \$̧, Gürdal B (2013). Check-List Of Additional Taxa To The Supplement Flora Of Turkey VI. J Fac Pharm Istanbul 43: $33-82$.

- $\quad$ Perveen A, Qaiser M (2007). Pollen morphology of family Solanaceae from Pakistan. Pakistan J Bot 39: 2243-2256.

- Pontis JA, Da Costa LAMA, Da Silva SJR, Flach A (2014). Color, phenolic and flavonoid content, and antioxidant activity of honey from Roraima, Brazil. Food Sci Tech-Brazil 34: 69-73. [CrossRef]
- $\quad$ Popova M, Silici S, Kaftanoglu O, Bankova V (2005). Antibacterial activity of Turkish propolis and its qualitative and quantita- tive chemical composition. Phytomedicine 12: 221-228. [CrossRef]

- $\quad$ Ruch RJ, Cheng SJ, Klaunig JE (1989). Prevention of cytotoxicity and inhibition of intercellular communication by antioxidant catechin isolated from Chinese green tea. Carcinogenesis 10: 10031008. [CrossRef]

- Sawicka D, Car H, Borawska MH, Nikliński J (2012). The anticancer activity of propolis. Folia Histochem Cytobio 50: 25-37. [CrossRef]

- Sforcin JM, Fernandes A, Lopes CAM, Bankova V, Funari SRC (2000). Seasonal effect on Brazilian propolis antibacterial activity. J Ethnopharmacol 73: 243-249. [CrossRef]

- Silva BB, Rosalen PL, Cury JA, Ikegaki M, Souza VC, Esteves A, Alencar SM (2008). Chemical composition and botanical origin of red propolis, a new type of Brazilian propolis. Evid-Based Compl Alt $\mathbf{5}$ 313-316. [CrossRef]

- Silva IAA., Da Silva TMS, Da Camara CA, Queiroz N, Magnani M, Novais JS, De Souza A GDe. (2013). Phenolic profile, antioxidant activity and palynological analysis of stingless bee honey from Amazonas, Northern Brazil. Food Chem 141: 3252-3258. [CrossRef]

- $\quad$ Slinkard K, Singleton V (1977). Total phenol analysis: automation and comparison with manual methods. Amer Soc Enology Viticulture 28: $49-55$.

- Sobočanec S, Balog T, Šari A, Mačak-Šafranko Ž, Štroser M, Žarković K, Marotti T (2011). Antitumor effect of Croatian propolis as a consequence of diverse sex-related dihydropyrimidine dehydrogenase (dpd) protein expression. Phytomedicine 18: 852-858. [CrossRef]

Wagh VD (2013). Propolis: A wonder bees product and its pharmacological potentials. Advances in Pharmacological Sciences 23 1-11. [CrossRef]

- Wali AF, Avula B, Ali Z, Khan IA, Mushtaq A, Rehman MU, Masoodi MH (2015). Antioxidant, hepatoprotective potential and chemical profiling of propolis ethanolic extract from Kashmir Himalaya region using Uhplc-Dad-Qtof-Ms. doi: 10.1155/2015/393462. [CrossRef]

Warakomska Z, Maciejewic W (1992). Microscopic analysis of propolis from Polish regions. Apidologie 23: 277-283 [CrossRef] 